\title{
Genetic diversity and structure of Ganoderma boninense isolates from oil palm and other plantation crops
}

\author{
AGUSTIAMAN PURBA ${ }^{1}$, RAHMAH HAYATI ${ }^{1}$, LOLLIE A.P. PUTRI ${ }^{2}$, DIANA CHALIL ${ }^{3}$, DADANG AFANDI $^{4}$, \\ INDRA SYAHPUTRA ${ }^{4}$, MOHAMMAD BASYUNI ${ }^{5 \varphi}$ \\ ${ }^{1}$ Graduate School of Agrotechnology, Faculty of Agriculture, Universitas Sumatera Utara. Jl. Dr. A Sofyan No. 3, Medan 20155, North Sumatra, \\ Indonesia \\ ${ }^{2}$ Department of Agrotechnology, Faculty of Agriculture, Universitas Sumatera Utara. J1. Dr. A Sofyan No. 3, Medan 20155, North Sumatra, Indonesia \\ ${ }^{3}$ Department of Agribusiness, Faculty of Agriculture, Universitas Sumatera Utara. Jl. Dr. A Sofyan No. 3, Medan 20155, North Sumatra, Indonesia \\ ${ }^{4}$ Laboratory of Biomolecular, PT Socfin Indonesia, Martebing, Dolok Masihul, Serdang Bedagai 20991, North Sumatra, Indonesia \\ ${ }_{5}^{5}$ Department of Forestry, Faculty of Forestry, Universitas Sumatera Utara. Jl. Tri Dharma Ujung No. 1, Medan 20155, North Sumatra, Indonesia. \\ Tel./fax.: +62-61-8201920, `email: m.basyuni@usu.ac.id
}

Manuscript received: 13 December 2019. Revision accepted: 6 January 2020.

\begin{abstract}
Purba A, Hayati R, Putri LAP, Chalil D, Afandi D, Syahputra I, Basyuni M. 2020. Genetic diversity and structure of Ganoderma boninense isolates from oil palm and other plantation crops. Biodiversitas 21: 451-456. Oil palm is an economically important plant, which one of the most important sources of vegetable oil in the world. However, oil palm plantation and other crops face the treat basal stem rot (BSR) disease by Ganoderma boninense. A study on genetic diversity and structure of G. boninense is therefore needed in order to formulate improved control strategies for this disease. This work aimed to analyze the genetic diversity and structure of the G. boninense isolates derived from different hosts, 131 oil palm (Elaeis guineensis), six rubber (Hevea brasiliensis), three coconuts (Cocos nucifera), and three lontar palm (Borassus flabellifer). Genetic diversity and population structure of G. boninense isolates were investigated using six SSR markers with GenAlex 6.502 software. Results showed that several microsatellite loci indicated specific primary success rates, such as KT124402, KT124399, and KT124394, depicting high polymorphism content (>75\%). This result suggested that these markers were equally effective in determining the polymorphisms of $G$. boninense isolates. A hierarchical analysis of molecular variance (AMOVA) revealed that genetic diversity mostly found among individuals within a population (88\%), then among populations (8\%), and within individuals (4\%).. Phylogeny analysis showed two clusters of Ganoderma isolates. which was considered variation as dissimilar across with origin. The present study indicated that G. boninense from oil palm was predominantly comprised of a genetically distinct individual.
\end{abstract}

Keywords: AMOVA, Ganoderma disease, microsatellite, polymorphism

Abbreviations: FBSR-CN: fruiting body basal stem rot-Cocos nucifera, FBSR-BF: fruiting body basal stem rot-Borassus flabellifer, FBSR-EG: fruiting body basal stem rot-Elaeis guineensis, FUSR-EG: fruiting body upper stem rot-E. guineensis, FBSR-HB: fruiting basal stem rot-Hevea Brasiliensis, FRWB-HB: fruiting body rubberwood block-H. brasiliensis, TUSR-EG: tissue upper stem rot-E. guineensis, TBSR-EG: tissue basal stem rot-E. guineensis, SBSR-EG: spore basal stem rot-E. guineensis, FB-EG: fruiting body-E. guineensis, T-EG: tissue-E. guineensis, FBD-EG: fruiting body died-E. guineensis, RFBS-EG: re-isolation fruit body seedling-E. guineensis, PDA: potato dextrose agar, WA: water agar.

\section{INTRODUCTION}

Oil palm (Elaeis guineensis) is an economically important plant, which one of the most important sources of vegetable oil in the world and a good fuel of biodiesel (Pleanjai and Shabbir 2009). A number of studies have been reported that Ganoderma boninense was a major pathogen causing diseases to attack oil palm (Paterson 2007), even to a lethal level (Hushiarian et al. 2013), coconut tree (Kandan et al. 2008), rubber tree (Sariah et al. 1994), lontar palm (Sankaran et al. 2005). Stem basal rot (SBR) has been reported to appear in various regions in Africa, includes Angola, Cameroon, Ghana, Nigeria, Zambia, Sao Tome, Tanzania, Zimbabwe and the Republic of the Congo; in America occurred in Honduras, and in Oceania found in Papua New Guinea, and South East Asia countries (Wang et al. 2009).
BSR can cause significant damage (Ishaq et al. 2014). Areas that constitute the BSR zone were North Sumatra and along the west coast of Peninsular Malaysia. Many infections occur with the appearance of the fruit body at the base of the plant. The spear leaves do not open, and canopy turns yellow (Breton et al. 2008). Oil palm, rubber, and tropical plantations crop suffer losses due to rootstock rot, caused by $G$. boninense (Caro et al. 2014), which is a fungus that causes death to plants. Many oil palm plantations experience considerable losses caused by the impact of disease of Ganoderma, used of planting materials that are resistant is needed (Purba et al. 2019). Total resistance to fungi has rarely been reported, but many examples have been observed, including in oil palm (Durand-Gasselin et al. 2014), rubber (Lim 1997), coconut (Zakaria 2005) and lontar palm (Rajendran et al. 2014). 
Furthermore, this disease was difficult to diagnose, and pathogens can be presented without the appearance of symptoms but have naturally infected plants (Corley and Tinker 2003). On the other hand, $G$. boninense has a slow growth development (Ho and Nawawi 1986) but has a long-lasting ability because of the resting spore and pseudosclerotium (Blanchette 1984). Darmono (1998) has reported that $G$. boninense found in Indonesia to have a molecular difference. In this circumstance, the phenotypic variation of $G$. boninense from several regions in Indonesia does not have very close relations (Purba et al. 2019). However, genetic diversity on $G$. boninense is not fully understood. Recently molecular performances showing the grouping of plant resistance to $G$. boninense occurred in healthy leaves of mature oil palm (Afandi et al. 2018). Furthermore, polyisoprenoid carbon chain-length has been shown to be a chemotaxonomic marker for the screening of oil palm resistance to $G$. boninense (Afandi et al. 2019. Therefore, a study on genetic diversity and structure of $G$. boninense is needed in order to formulate improved control strategies for this disease. The present work aimed to investigate the genetic diversity and structure of the $G$. boninense isolates from mostly E. guineensis and other plantation crops.

\section{MATERIALS AND METHODS}

\section{Ganoderma boninense isolates}

The materials used in this work were 147 Ganoderma boninense isolates, which were from different hosts, 131 oil palm (Elaeis guineensis), six rubber (Hevea brasiliensis), three coconuts (Cocos nucifera), and three lontar palm (Borassus flabellifer). These isolates were derived from the Pathology Laboratory of PT Socfin Indonesia collections. The isolates were initially from North Sumatra (Serdang Bedagai, Asahan, Simalungun, Tebing Tinggi, Central Tapanuli, Batubara, Labuhan Batu Utara, and Medan), West Sumatra, South Sumatra, and Sulawesi, Indonesia. Source of isolates were grouped as 13 populations that previously described (Purba et al. 2019) as follows. FBSR$\mathrm{CN}$ (fruiting body basal stem rot-Cocos nucifera), FBSRBF (fruiting body basal stem rot-Borassus flabellifer), FBSR-EG (fruiting body basal stem rot-Elaeis guineensis), FUSR-EG (fruiting body upper stem rot-E. guineensis), FBSR-HB (fruiting basal stem rot-Hevea Brasiliensis), FRWB-HB (fruiting body rubberwood block- $H$. brasiliensis), TUSR-EG (tissue upper stem rot- $E$. guineensis), TBSR-EG (tissue basal stem rot-E. guineensis), SBSR-EG (spore basal stem rot- $E$. guineensis), FB-EG (fruiting body-E. guineensis), T-EG (tissue-E. guineensis), FBD-EG (fruiting body died-E. guineensis), RFBS-EG (re-isolation fruit body seedling-E. guineensis). The majority of isolates were sourced from oil palm (Elaeis guineensis Jacq., Arecaceae).

\section{Growth of Ganoderma boninense isolates on potato dextrose agar (PDA)}

The growth of $G$. boninense isolates was carried out as previously reported (Purba et al. 2019). Briefly, the isolates were conserved, stored in an incubator at $20^{\circ} \mathrm{C}$. Preparation of isolates was carried out in laminar airflow under sterile conditions. Mycelium was taken from pieces of PDA (potato dextrose agar) from a Wheaton tube using a needle, then subcultured into water agar (WA) media (+chloramphenicol, streptomycin) in three petri dishes, which was prepared for five days before the subculture performed. Mycelium, which grows on WA media, was subcultured into the PDA (+chloramphenicol) medium of five petri dishes, which have been prepared five days before subculture was carried out (Naher et al. 2012). Then, the $G$. boninense isolates incubated in dark conditions at $28^{\circ} \mathrm{C}$ for ten days, as shown in Figure 1 .

\section{The DNA extraction}

Ganoderma boninense mycelium, which has been grown on the PDA media, were used for DNA extraction. Total DNA was extracted from B. boninense using the CTAB method, as previously described with minor modification (Basyuni et al. 2017). The DNA quality was tested based on UV-illuminator and documented using the Gel doc. DNA was quantified using the nanophotometer method, using wavelengths $(\lambda) 260$ and $280 \mathrm{~nm}$.

\section{PCR Amplification}

In this study, the SSR (Simple Sequence Repeat) primers for the Polymerase Chain Reaction (PCR) used 6 primers pairs (Table 1) as previously reported (Merciere et al. 2015). Amplification reaction for PCR was done in 10 $\mu \mathrm{l}$ of the total volume containing $3 \mu \mathrm{L}$ of DNA templates mixed with $2.5 \mu \mathrm{L}$ Gotaq master, $0.5 \mu \mathrm{L}$ forward primer and $0.5 \mu \mathrm{L}$ reverse, primer and $3.5 \mu \mathrm{L} \mathrm{ddH}_{2} \mathrm{O}$.

PCR amplification was performed on Eppendorf Mastercycler ep 384 (Eppendorf, Westbury, New York, USA). The amplification program consisted 35 cycles at $95^{\circ} \mathrm{C}$ for $4 \mathrm{~min}$, followed by $10 \mathrm{sec}$ at $94^{\circ} \mathrm{C}$, annealing at $52^{\circ} \mathrm{C}$ for $75 \mathrm{sec}$, and elongation were processed at $72{ }^{\circ} \mathrm{C}$ for $90 \mathrm{sec}$ and a final extension at $72^{\circ} \mathrm{C}$ for $8 \mathrm{~min}$. PCR product was performed by electrophoresis and documented with UV-transilluminator (UV-Doc) and Gel-Doc (U Doc) as previously described (Afandi et al. 2018).

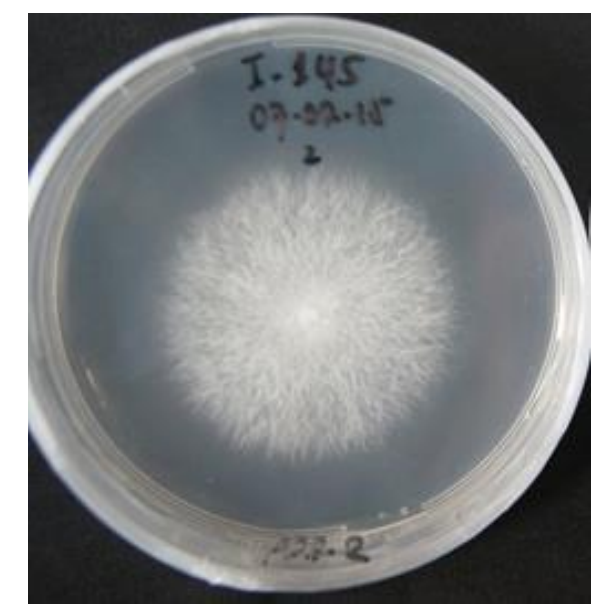

Figure 1. The mycelium Ganoderma boninense have been grown on PDA 
Table 1. Description of primer sequences used to this study

\begin{tabular}{clc}
\hline Primer & \multicolumn{1}{c}{ Primer sequences (5'-3') } & $\begin{array}{c}\text { Amplicon } \\
\text { (bp) }\end{array}$ \\
\hline KT124397 F: CGCCATGCCCACCACCAGAG & $283-325$ \\
& R: GACCCGGCTGCCCGAATGAG & \\
KT124402 F:ACAAGGCTCAAGGCAGCGCA & $212-224$ \\
& R: GCACACCCCAGCAACAGGAGG & \\
KT124403 F: GGCGACGAGGGCACGAGAGA & $273-297$ \\
& R:CCGCACTTTCGCCAACCACC & \\
KT124400 F:AGCTCCCCTCCCAGCTCCAAC & $171-186$ \\
& R:GAATGCGGCGGGGAAACGGA & \\
KT 124399 F:GCACAGGCACAAGCGCAAGG & $204-267$ \\
& R:CGACGACCGCCCCAAAGGAT & \\
KT 124394 F:CGGGAAGTGGTGAACGGTGGT & $234-243$ \\
& R:GGGTGGCTTGACAGCGGCAT & \\
\hline
\end{tabular}

Tabel 2. F-Statistics, total migrant and polymorphic information overall population

\begin{tabular}{llllll}
\hline Loci & Fis & Fit & Fst & Nm & PIC \\
\hline KT124397 & 0.80 & 0.86 & 0.31 & 0.57 & 0.56 \\
KT124402 & 1.00 & 1.00 & 0.44 & 0.32 & 0.92 \\
KT124403 & 0.78 & 0.85 & 0.31 & 0.56 & 0.53 \\
KT124400 & 1.00 & 1.00 & 0.42 & 0.34 & 0.15 \\
KT124399 & 0.76 & 0.85 & 0.38 & 0.41 & 1.00 \\
KT124394 & 0.71 & 0.83 & 0.40 & 0.38 & 0.76 \\
Mean & 0.84 & 0.90 & 0.37 & 0.43 & 0.65 \\
SE & 0.05 & 0.03 & 0.02 & 0.04 & 0.12 \\
\hline
\end{tabular}

Note: Allele frequency correlations between individuals in the subpopulation (Fis), allele frequency in the population caused by Fis and Fst (Fit), allele frequency correlations between subpopulation (Fst), the total of migrants $(\mathrm{Nm})$, polymorphic information content (PIC).

\section{Microsatellite data analysis}

Genetic differentiation for each population and locus were assessed by calculating using GenAlEx ver 6.502 (Peakal and Smouse 2012) as frequency by alleles correlations between individuals in subpopulations (Fis), correlation of frequency between subpopulations (Fst), frequency by alleles in population caused by both factors (Fit), total migrants $(\mathrm{Nm})$, number of different alleles $(\mathrm{N})$, number of different allele frequencies $>0.5 \%(\mathrm{Na})$, Number of active alleles (Ne) and Shannon of Information index (I). The polymorphisms for each population and locus were assessed by calculating the observed average heterozygosity (Ho), expected heterozygosity (He), and fixation index (F) (Nei 1978). Polymorphic Information Content (PIC) was determined by Avval (2017). The genetic structure analyzed was calculated using the GenAlEx analysis of molecular variance (AMOVA) ver 6.502 package (Peakal and Smouse 2012).

\section{Phylogenetic analysis}

Phylogenetic analysis was done based on the accession and grouping analysis of the phylogenetic tree of Ganoderma boninense isolates. Forward, they were analyzed using the Unweighted Pair Group Method with
Arithmetic Mean (UPGMA) by MVSP ver. 3.22 software (Basyuni et al. 2018).

\section{RESULTS AND DISCUSSION}

\section{Selection of polymorphism marker}

We identified of $G$. boninense isolates in six loci (KT124397, KT124402, KT124403, KT124400, KT124399 and KT124394) and 13 populations. Interpretation of genetic variation and interaction of locus frequencies between alleles was a collaboration between individual alleles and indicated Fis (0.84), as displayed in Table 2. The average frequency of the different isolate populations in the alleles identified was 0.90 (Fit). Wherein the second factor was obtained by Fst $(0.37)$, while the maximum Fis (1.00) and Fit (1.00), the minimum Fis (0.71), and Fit (0.83). Total migration $(\mathrm{Nm})$ by the mean number of alleles was 0.43 within populations; PIC 0.65 mean observed (Table 2). The PIC value of each SSR primers was determined by the number of alleles and the frequency of distribution within a population, wherein high PIC was $>0.5$, moderate $0.5>$ PIC $>0.25$, and low PIC was $<0.25$ (Bhattacharya et al. 2010). The polymorphic of this study ranged from 0.15 to 1.0 within thirteen populations. This genetic variation indicated that the genetic diversity within the population was very low in KT124400 loci (0.15) but higher in KT124399 loci (1.00). Among three loci, as reported by Merciere et al. (2015) showed the same mean PIC was KT124397 (0.56), KT124403 (0.53), and KT124394 (0.76) respectively.

This study suggested that some microsatellite loci data indicated specific primary success rates, this result showed only for locus KT124402, KT124399, and KT124394. There are not effective polymorphism locus within KT124400. The high level for a polymorphic recommendation (PIC $>0.5)$ of SSR markers and suggested that these markers were effective in determining the polymorphisms of Ganoderma isolates. The present study supported the previous reports (Afandi et al. 2018) that molecular markers to be considered as promising markers for $G$. boninense resistance screening oil palm. In addition to the polyisoprenoid pattern in E. guineensis as a potential biochemical marker in response to $G$. boninense infection (Afandi et al. 2019).

\section{Microsatellite analysis for each population}

Table 3 shows the microsatellite for the population of $G$. boninense isolates. The average number of alleles $(\mathrm{N})$ for each population from 2.50 to 21.00 , was observed. The highest value found in RFBS-EG was 21.00. The mean number of different alleles frequency $>0.5 \%$ found (8.10); this value was similar to those previously reported for Ganoderma boninense (8.00) (Merciere et al. 2015). Estimated $\mathrm{Ne}$ values averaged 6.64 varying from 1.00 to 21.57 (Table 3), indicating that most individuals were necessary for one population or another one. However, I value ranging from 0.00 to 3.24 , with an average was 1.45 . 
Table 3. The profile of microsatellite loci for all population of Ganoderma boninense isolates

\begin{tabular}{lcccccccc}
\hline \multicolumn{1}{c}{ Population } & $\mathbf{N}$ & $\mathbf{N a}$ & $\mathbf{N e}$ & $\mathbf{I}$ & Ho & He & uHe & F \\
\hline FBSR-CN & 2.50 & 3.17 & 2.93 & 1.11 & 0.31 & 0.66 & 0.83 & 0.52 \\
FBSR-BF & 2.83 & 3.00 & 2.84 & 1.05 & 0.14 & 0.63 & 0.77 & 0.79 \\
FBSR-EG & 51.33 & 30.83 & 21.57 & 3.24 & 0.03 & 0.95 & 0.96 & 0.97 \\
FUSR-EG & 20.00 & 16.33 & 12.82 & 2.66 & 0.03 & 0.92 & 0.94 & 0.97 \\
FBSR-HB & 3.00 & 2.33 & 2.23 & 0.69 & 0.28 & 0.42 & 0.50 & 0.39 \\
FRWB-HB & 3.00 & 3.50 & 3.07 & 1.06 & 0.50 & 0.57 & 0.68 & 0.19 \\
TUSR-EG & 17.00 & 12.33 & 10.18 & 2.37 & 0.00 & 0.89 & 0.91 & 1.00 \\
TBSR-EG & 11.00 & 9.00 & 8.20 & 2.13 & 0.00 & 0.87 & 0.91 & 1.00 \\
SBSR-EG & 3.00 & 1.67 & 1.53 & 0.42 & 0.00 & 0.30 & 0.36 & 1.00 \\
FB-EG & 5.00 & 4.00 & 3.62 & 1.29 & 0.00 & 0.69 & 0.77 & 1.00 \\
T-EG & 3.00 & 1.00 & 1.00 & 0.00 & 0.00 & 0.00 & 0.00 & 1.03 \\
FBD-EG & 3.00 & 1.00 & 1.00 & 0.00 & 0.00 & 0.00 & 0.00 & 0.50 \\
RFBS-EG & 21.00 & 17.17 & 15.26 & 2.78 & 0.00 & 0.93 & 0.96 & 0.89 \\
Mean & 11.21 & 8.10 & 6.64 & 1.45 & 0.10 & 0.60 & 0.66 & 0.82 \\
SE & 1.53 & 0.99 & 0.76 & 0.12 & 0.03 & 0.04 & 0.04 & 0.04 \\
\hline N & & & & & & & &
\end{tabular}

Note: A number of different alleles $(\mathrm{N})$, number of different alleles frequency> $0.5 \%(\mathrm{Na})$, number of effective alleles (Ne), and Shannon of information index (I), observed heterozygosity (Ho), expected heterozygosity (He), unbiased expected heterozygosity (uHe), fixation index (F). FBSR-CN (fruiting body basal stem rot-Cocos nucifera), FBSR-BF (fruiting body basal stem rot-Borassus flabellifer), FBSR-EG (fruiting body basal stem rot-Elaeis guineensis), FUSR-EG (fruiting body upper stem rot-E. guineensis), FBSRHB (fruiting basal stem rot-Hevea Brasiliensis), FRWB-HB (fruiting body rubberwood block-H. brasiliensis), TUSR-EG (tissue upper stem rot-E. guineensis), TBSR-EG (tissue basal stem rot-E. guineensis), SBSR-EG (spore basal stem rot-E. guineensis), FB-EG (fruiting body-E. guineensis), T-EG (tissue- $E$. guineensis), FBD-EG (fruiting body died-E. guineensis), RFBS-EG (re-isolation fruit body seedling-E. guineensis)

Table 4. Summary analysis of molecular variance (AMOVA) of Ganoderma boninense isolates population

\begin{tabular}{lccccc}
\hline Source & df & SS & MS & Est. Var. & \% var \\
\hline Among populations & 12 & 122.51 & 10.21 & 0.24 & 8 \\
Among individuals & 134 & 724.88 & 5.41 & 2.65 & 88 \\
Within individuals & 147 & 16.50 & 0.12 & 0.11 & 4 \\
Total & 293 & 863.89 & & 3.00 & 100 \\
\cline { 1 - 2 }
\end{tabular}

Note: df: Degree of Freedom, SS: Source of Variation, MS: Mean Squares, Est.Var: Estimation of Variant, Var: Variant

Allelic diversity by samples was estimated using heterozygosity ( $\mathrm{Ho}$ and $\mathrm{He}$ ). It is interesting to note that seven populations had Ho (0.00); these values could not be detected in samples TUSR-EG, TBSR-EG, SBSR-EG, FBEG, T-EG, FBD-EG, and RFBS-EG. Furthermore, the others were successfully detected, the range value Ho from 0.03 to 0.31 . A more appropriate measure of genetic variation in population was genes diversity (mean expected heterozygosity). He, in this population, was average (0.60), which was in the range $(0.30$ to 0.95$)$ to be useful for measuring genetic variation with population $\mathrm{T}-\mathrm{EG}$ and FBD-EG were not detected $(\mathrm{He}=0.00)$. One of the factors that affects the dendrogram is the level of heterozygosity, in some organisms with average heterozygosity higher than 0.1 to construct a reliable dendrogram (Nei 1978). Genetic diversity was assessed by calculating unbiased expected heterozygosity (Raymond and Rousset 1995). uHe among population T-EG and FBD-EG are not detected (0.00), and using an average, the fixation index $(F)$ of the population was 0.82 . On the other hand, the Ganoderma isolates from Belitung Island have been reported with He of 0.77 (Jiat et al. 2019). Moreover, Merciere et al. (2015) have reported that the average He was 0.59 for $G$. boninense isolates, was similar to this study.

\section{Genetic structure of Ganoderma boninense}

The genetic structure of $G$. boninense was carried out by hierarchical analysis of molecular variance (AMOVA) using on the infinite alleles model (F-statistics). Table 4 shows locus by AMOVA analysis, which was done to undertake the populations as sources of variation. In this case, results derived from GeneAlex programs provide strong support of a $G$. boninense isolates origin $C$. nucifera, B. flabellifer, E. guineensis, and H. brasiliensis. This SSR marker seems to be worthy, mainly genetic diversity. The high average percentage of the source of variation (724.88) among individual, pointed out the genetic differences among individuals within populations.

In addition, AMOVA indicated the degree of freedom that 134 of the total genetic variation. While the mean square was 5.41 corresponded to the distinction among individuals. Percentages among individuals within the population were $88 \%$ variant, among populations was low $(8 \%)$, and within an individual $(4 \%)$ were estimated. This 
genetic structure of $G$. boninense varied among the individuals was supported by the previous report that population structure could be the result of an arrangement of long-surviving isolates, possibly from adjacent areas planted with coconut and oil palm (Pilotti et al. 2003). Recently, Merciere et al. (2017) have reported on the AMOVA results that $G$. boninense had a very low variation between regions $(1.59 \%)$ and between plantations (0.97), but a very high variation within samples $(97.44 \%$,), totally agreed with the present study.

\section{Phylogenetic analysis of $G$. boninense}

We identified the genetic variation from thirteen populations of FBSR-CN (fruiting body basal stem rotCocos nucifera), FBSR-BF (fruiting body basal stem rotBorassus flabellifer), FBSR-EG (fruiting body basal stem rot-Elaeis guineensis), FUSR-EG (fruiting body upper stem rot-E. guineensis), FBSR-HB (fruiting basal stem rotHevea Brasiliensis), FRWB-HB (fruiting body rubberwood block- $H$. brasiliensis), TUSR-EG (tissue upper stem rot- $E$. guineensis), TBSR-EG (tissue basal stem rot- $E$. guineensis), SBSR-EG (spore basal stem rot-E. guineensis), FB-EG (fruiting body-E. guineensis), T-EG (tissue-E. guineensis), FBD-EG (fruiting body died-E. guineensis), RFBS-EG (re-isolation fruit body seedling-E. guineensis). It showed in Figure. 2. The dendrogram (UPGMA) showed two large groups in the population. The first group consisting of population was RFBS-EG, FB-EG, FBD-EG, T-EG, SBSR-EG, TBSR-EG, TUSR-EG, FUSREG and FBSR-EG. The second group consisted mainly of only four populations from FBSR-HB, FRWB-HB, FBSRBF, FBSR-CN. Dendrogram was concluded that the clades represented separated populations of origin. G. boninense distinct most closely related to isolates from E. guineensis (cluster I) dissimilar with isolates from H.Brasiliensis (cluster II), B. flabellifer (cluster III) and C.nucifera (cluster IV). This study supported likewise Ganoderma boninense is the major disease factor to E. guineensis plantations in the world (Gorea et al. 2019). On the other hand, Ganoderma sp. have been reported from the tea and rubber plantation were more closely related compared to oil palm and the forest trees, furthermore, the species were identified especially to $G$. boninense from $E$. guineensis and C.nucifera, whereas G. philippii from H. brasiliensis (Nusaibah et al. 2011). Ganoderma disease caused by $G$. psuedoferreum has been reported caused fruiting bodies were seen in the $H$. brasiliensis stumps in the plantation (Ogbebor et al. 2010).

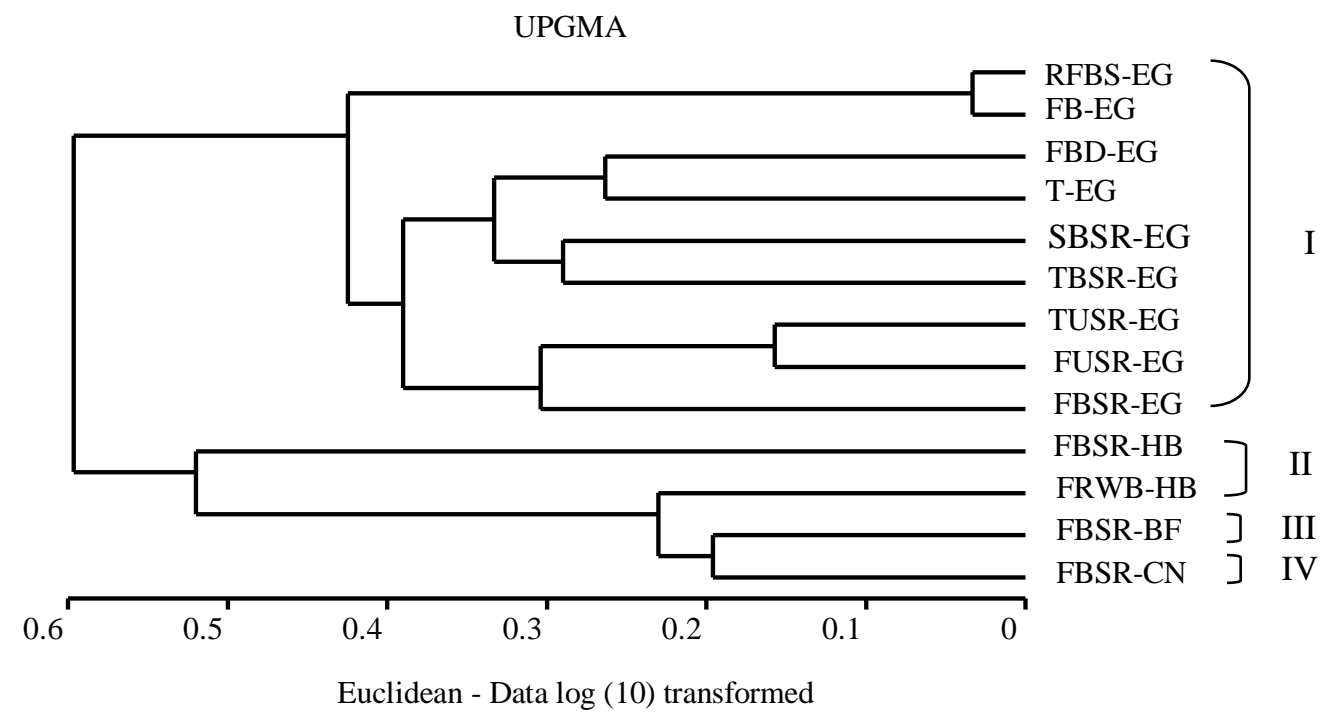

Figure 2. Cluster analysis of Ganoderma boninense isolates from 13 populations. FBSR-CN (fruiting body basal stem rot-Cocos nucifera), FBSR-BF (fruiting body basal stem rot-Borassus flabellifer), FBSR-EG (fruiting body basal stem rot-Elaeis guineensis), FUSR-EG (fruiting body upper stem rot-E. guineensis), FBSR-HB (fruiting basal stem rot-Hevea Brasiliensis), FRWB-HB (fruiting body rubberwood block-H. brasiliensis), TUSR-EG (tissue upper stem rot-E. guineensis), TBSR-EG (tissue basal stem rot-E. guineensis), SBSR-EG (spore basal stem rot-E. guineensis), FB-EG (fruiting body-E. guineensis), T-EG (tissue-E. guineensis), FBD-EG (fruiting body died-E. guineensis), RFBS-EG (re-isolation fruit body seedling-E. guineensis). 
In conclusion, this work confirmed that $G$. boninense had high genetic diversity among the individual within populations. Management factors such as the origin between isolates could be the significant cause $G$. boninense population isolates. Several SSR markers were promisingly effective in determining the polymorphisms of $G$. boninense isolates. This study clarified that $G$. boninense from oil palm was predominantly comprised of a genetically distinct individual.

\section{ACKNOWLEDGEMENTS}

This study was supported by an Applied Grant (No.28/UN5.2.3.1/PPM/KP-DPRM/2019) from Directorate for Research and Community Service, Ministry of Research, Technology and Higher Education, Republic of Indonesia.

\section{REFERENCES}

Afandi D, Basyuni M, Putri LA, Chalil D, Wati R, Siregar EB, Syahputra I. 2018. Molecular performances of oil palm (Elaeis guineensis) tolerance to Ganoderma sp. IOP Conf. Ser: J Phys: Conf. Ser 1116 : 052001. DOI:10.1088/1742-6596/1116/5/052001.

Afandi D, Basyuni M, Putri LAP, Chalil D, Syahputra I. 2019. Expression of oil palm (Elaeis guineensis) polyisoprenoids in response to Ganoderma boninense infection. Biodiversitas 20: 68-76.

Avval SE. 2017. Assessing polymorphism information content (PIC) using SSR molecular markers on local species of Citrullus colocynthis. Case study: Iran, Sistan-Balouchestan province. J Mol Biol Res 7: 42-49.

Basyuni M, Baba S, Oku H. 2017. Microsatellite analysis on genetic variation in two populations of red mangrove Rhizophora mangle $\mathrm{L}$. (Rhizophoraceae) and its implication to conservation. IOP Conf Ser: Mater Sci Eng 180: 012243.

Basyuni M, Wati R, Deni I, Tia AR, Siregar ES, Syahputra I. 2018. Cluste analysis of polyisoprenoid in oil palm (Elaeis guineensis) leaves in different land-uses to find the possible cause of yield gap from planting materials. Biodiversitas 19: 1492-1501.

Bhattacharya S, Bandopadhyay TK, Ghosh EPD. 2010. Efficiency of RAPD and ISSR markers in assessment of molecular diversity in elite germplasms of Cymbopogon winterianus across West Bengal, India. J Food Agric 22: 13-24.

Blanchette RA. 1984. Selective delignification of eastern hemlock by Ganoderma tsugae. Phytopathology 74 (2): 153-160.

Breton F, Miranti R, Lubis Z, Hayun Z, Setiawati U, Flori A, Nelson S, Durand GT, Jacquemard JC, Hubert DF. 2009. Implementation of an early artificial inoculation test to screen oil palm progenies for their level of resistance and hypothesis on natural infection. The 5th Quadrennial International Oil Palm Conference, Bali Nusa Dua Convention Center, Indonesia, 17-19 June 2014.

Caro ML, Rimbawanto A, Page DE. 2014. Management of basidiomycete root and stem rot diseases in oil palm, rubber, and tropical hardwood plantation crops. For Pathol 44: 428-446.

Corley RHV, Tinker PB. 2003. The Oil Palm. 4th ed. Blackwell Publishing, London.

Darmono TW. 1998. Variation among isolates of Ganoderma sp. from oil palm in Indonesia. Second International Workshop on Ganoderma Disease, Malaysia.

Durand-Gasselin T, Noiret JM, Kouamé KR, Cochard B, Adon B. 1999. Availability of quality pollen for improved oil palm (Elaeis guineensis Jacq.) seed production. Plantations, Recherche, Développement 6: 264-276.

Gorea EA, Godwin ID, Mudge AM. 2019. Ganoderma infection of oil palm-a persistent problem in Papua New Guinea and Solomon Islands. Australasian Plant Pathol. DOI: 10.1007/s13313-019-006739
Ho YW, Nawawi A. 1986. Isolation, growth and sporophore development of Ganoderma boninense from oil palm in Malaysia. Pertanika 9: 6973.

Hushiarian, Roozbeh, Nor AY, Sabo WD. 2013. Detection and control of Ganoderma boninense: strategies and perspectives. Springer Plus 2 (1): 555.

Ishaq I, Alias MS, Kadir J, Kasawani I. 2014. Detection of basal stem rot disease at oil palm plantations using sonic tomography. J Sustain Sci Manag 9: 52-57.

Jiat TH, Astari S, Keng G, Joo G, Chee WW. 2019. cDNA-SSR markers for molecular epidemiology of Ganoderma boninense. J Oil Palm Res 31 (2): 220-237.

Kandan AR, Bhaskaran R, Samiyappan R. 2010. Ganoderma-a basal stem rot disease of coconut palm in south Asia and Asia Pacific regions. Arch Phytol Plant Prot 43: 1445-1449

Lim TM. 1977. Production, germination and dispersal of basidiospores of Ganoderma pseudoferreum on Hevea. J Rubber Res Inst Malaya 25 (2): 93-99.

Merciere M, Boulord R, Carasco-Lacombe C, Klopp C, Lee YP, Tan JS, Alwee SSRS, Zaremski A, De Franqueville H, Camus-Kulandaivelu L. 2017. About Ganoderma boninense in oil palm plantations of Sumatra and peninsular Malaysia: Ancient population expansion, extensive gene flow and large scale dispersion ability. Fungal Biol 121 (6-7): 529-540.

Mercière M, Laybats A, Lacombe CC, Tan JS, Klopp C, Gasselin TD, Alwee SSRS, Kulandaivelu LC, Breton F. 2015. Identification and development of new polymorphic microsatellite markers using genome assembly for Ganoderma boninense, causal agent of oil palm basal stem rot disease. Mycol Prog 14: 103.

Naher L, Yusuf UK, Siddiquee S, Ferdous J, Rahman MA. 2012. Effect of media on growth and antagonistic activity of selected Trichoderma strains against Ganoderma. Afr J Microbiol Res 6 (48): 7449-7453.

Nei M. 1978. Estimation of average heterozygosity and genetic distance from a small number of individuals. J Genet 89: 583-590

Nusaibah SA, Latiffah Z, Hassaan AR. 2011. ITS-PCR-RFLP analysis of Ganoderma sp. Infecting industrial crops. Pertanika J Trop Agric Sci 34 (1): 83-91.

Ogbebor N, Adekunle A, Eghafona N, Ogboghodo A. 2010. Ganoderma psuedoferreum: biological control possibilities with microorganisms isolated from soils of rubber plantations in Nigeria. Afr J Agric Res 6: 301-305.

Paterson RRM. 2007. Ganoderma disease of oil palm-A white rot perspective necessary for integrated control. Crop Prot 26.9: 13691376

Peakall R, Smouse PE. 2012. GenAlEx 6.5: genetic analysis in Excel. Population genetic software for teaching and research-an update. Bioinformatics 28: 2537-2539.

Pilotti, CA. Sanderson FR, Aitken EAB. 2003. Genetic structure of a population of Ganoderma boninense on oil palm. Plant Pathol 52: 455-463.

Pleanjai S, Shabbir HG. 2009. Full chain energy analysis of biodiesel production from palm oil in Thailand. Appl Energy 86: S209-S214.

Purba A, Basyuni M, Putri LA, Chalil D, Hayati R, Arifiyanto D, Syahputra I. 2019. Sequence analysis of Ganoderma boninense isolates from oil palm. IOP Conf Ser: Earth Environ Sci 260: 012172.

Rajendran L, Akila R, Karthikeyan G, Raguchander T, Saravanakumar D, Samiyappan R. 2014. Nucleic acid-based detection technique for Ganoderma lucidum in coconut. Archiv Phytopathol Plant Prot 47 (6): 690-702

Raymond M., Rousset F. 1995. Genepop (version 1.2): population genetics software for exact tests and ecumenicism. J Hered 86: 248249.

Sankaran KV, Bridge PD, Gokulapalan C. 2005. Ganoderma diseases of perennial crops in India-an overview. Mycopathologia 159: 143-152.

Sariah M, Hussin MZ, Miller RNG, Holderness M. 1994. Pathogenicity of Ganoderma boninense tested by inoculation of oil palm seedlings. Plant Pathol 43 (3): 507-510.

Wang, Dong M, Sheng HW, Ching HS, Jin TP, Ya HS, Lung CC. 2009. Ganoderma multipileum, the correct name for ' $G$. lucidum' in tropical Asia. Bot Stud 50: 451-458

Zakaria L, Kulaveraasingham K, Tan SG, Abdullah F, Ho YW. 2005. Random amplified polymorphic DNA (RAPD) and random amplified microsatellite (RAMS) of Ganoderma from Infected oil palm and coconut stumps in Malaysia. Asia Pac J Mol Biol Biotechnol 13 (1): 23-34. 